\title{
Particle associated polycyclic aromatic hydrocarbons in the atmospheric environment of urban and suburban residential area
}

\author{
${ }^{1^{*}}$ M. A. Salam ; ${ }^{2}$ Y. Shirasuna $;{ }^{2}$ K. Hirano $;{ }^{1}$ S. Masunaga \\ ${ }^{1}$ Graduate School of Environment and Information Science, Yokohama National University, \\ Yokohama, Japan \\ ${ }^{2}$ Yokohama City Research Institute for Environmental Science, Yokohama, Japan
}

Received 9 October 2010; revised 30 November 2010; accepted 1 February 2011; $\quad$ available online 1 March 2011

\begin{abstract}
Ten polycyclic aromatic hydrocarbons associated with suspended particulate matter in the ambient air were collected at two sampling sites: urban and suburban residential areas of Yokohama, Japan from 1999 to 2005. The concentrations of target compounds were determined using gas chromatography-mass spectrometry. The total concentrations were higher in urban residential area than suburban residential area. They ranged from 0.31 to $6.16 \mathrm{ng} / \mathrm{m} 3$ with a mean of $2.07 \mathrm{ng} / \mathrm{m} 3$ and 0.33 to $2.87 \mathrm{ng} / \mathrm{m} 3$ with a mean of $1.02 \mathrm{ng} / \mathrm{m} 3$ in the urban and suburban residential areas, respectively. The predominant compounds determined both in the urban and suburban residential areas were benzo[b]fluoranthene, benzo[ghi]perylene, indeno[1,2,3-cd]pyrene and benzo[e]pyrene. The concentrations of 5- and 6-ring polycyclic aromatic hydrocarbons were higher in the urban than the suburban residential area, accounting for 77.3 $\%$ and $72.1 \%$ of total polycyclic aromatic hydrocarbons, respectively. Source identification was performed by principal component analysis. Two principal components were identified for each study area and these accounted for $95.9 \%$ and $83.3 \%$ of total variance, respectively. The results revealed that stationary source and vehicle emissions were the major pollution sources in the studied areas. The impact of emission regulations for automobiles in large Japanese cities, which were enacted during 2002 and 2003, was also studied. Based on the average total concentration, emission reduction was $47.8 \%$ and $18.6 \%$ in urban residential and suburban residential areas, respectively.
\end{abstract}

Keywords: Emission regulation; Source identification; Suspended particulate matter; Vehicle emission

\section{INTRODUCTION}

Air pollution has adverse effects on respiratory and cardiovascular health such as acute reduction in lung function, aggravation of asthma, increased risk of pneumonia in the elderly, low birth weight and higher death in newborns (Wilson et al., 2004). The chemical composition of suspended particulate matter (SPM) in polluted atmosphere has become a topic of considerable importance over recent years in relation to public health. Several epidemiological studies have demonstrated strong associations between the levels of particulate matter and the prevalence of increased lung cancer, mortality and morbidity (Dockery et al., 1993; Pope et al., 1995a, b; Pozzi et al., 2005; World Health Organization Europe, 2005; Pope and Dockery, 2006; Chakra et al., 2007). In Japan, health implications of SPM have been well-documented (Omori et al., 2003;

《*Corresponding Author Email: s_salam1978@yahoo.com Tel.: +81 45339 4371; Fax: +81 453394373
Yorifuji et al., 2005; Murakami and Ono, 2006; Yamazaki et al., 2007). Consequently, SPM has been recognized as a potent air pollutant in urban areas of Japan and considered as a criteria pollutant to be routinely monitored in ambient air. SPM pollution has been linked to bear remarkable effect on global climate change, too (Jacobson, 2002; Bandyopadhyay and Chattopadhyay, 2007; Feng et al., 2009; Wu and He, 2010). Although there is still a fundamental lack of understanding of the underlying mechanisms of their toxicity, one of the widely accepted hypotheses is that particulate toxicity not only depends on their size but also on their composition (Harrison and Yin, 2000; He et al., 2011). Studies performed on SPM revealed that organic compounds like polycyclic aromatic hydrocarbons (PAHs) absorbed on particulate matter probably play an important role during the generation of adverse health effects (Gilli et al., 2007; Skarek et al., 2007). 
PAHs resulting from incomplete combustion are of special interest due to their toxicity, carcinogenicity, mutagenicity and ubiquitous presence in the environment (McCrillis et al., 1992). These adverse properties demand an assessment of their concentration, trends and source profile in the atmosphere to provide an aid to manage regional air pollution control strategies (Ravindra et al., 2001; Breivik et al., 2006). Atmospheric PAHs are partitioned between the particulate and gaseous phases. However, the carcinogenic 5- and 6-ring species are predominantly associated with particles, especially those falling in the accumulation mode (Venkataraman et al., 1994, Manoli et al., 2004; Mantis et al., 2005). The occurrence of specific PAH compounds or a group of PAHs, have been used to indicate the corresponding emission sources (Venkataraman et al., 1994; Khalili et al., 1995; Goyal et al., 2008). Major PAH sources to the atmosphere include motor vehicles, home heating and fossil fuel combustion. Other sources of PAHs in the environment include lubricating oils, atmospheric deposition, power plants and various industrial activities (Khanfekr et al., 2009; Arulazhagan et al., 2010; Fagbote and Olanipekun, 2010). Automobile is an extremely important segment of modern human society. The impact of automobile emission on environment, predominantly on soil, air and water is increased day by day. Automobile emissions have shown a tremendous impact on the environment during the last few years (Kumar and Kothiyal, 2011). Proliferation of motor transport, rather than industrial activities, is advanced in political and/or commercial cities as providing the main contribution to growing levels of pollution such as PAHs. As a result, the Government of Japan introduced legislation along with other measures targeted at reducing vehicular emissions and promoting the use of low-pollution vehicles (Japan Environmental Council, 2003). Thus, the study of the occurrence of SPM associated PAHs and the process governing their fate is undoubtedly of great importance.

Due to the extreme complexity of particle characteristic in the atmosphere, the source and sink scenario of particulate PAHs have yet to be fully understood. Most of the studies in Yokohama City on particulate PAHs have been conducted with limited number of samples within a year. To the best of our knowledge, no study was conducted to evaluate the impact of vehicular emission which was enacted in 2002 and 2003 across the large Japanese city. Present study was conducted intensively with higher number of samples collected from April, 1995 to May, 2005 in Yokohama City, Japan. The aim of the present study was to explore location specific assessment of the concentration, trend and sources of SPM contained PAHs in the atmosphere. The impact of the emission regulations for automobiles in large Japanese cities, which were enacted during 2002 and 2003, was also studied from the samples collected in urban residential and suburban residential areas of Yokohama.

\section{MATERIALS AND METHODS}

Sampling sites

Ambient air samples were collected at two sites namely urban residential and suburban residential areas (Fig. 1) of Yokohama, Japan. The urban residential site was located at the Hiranuma Elementary School, Nishi Ward and very close to downtown of Yokohama. In the vicinity of the site are a play ground, high traffic density as well as industrial activities. The suburban residential site was located at Nagahama, Kanazawa Ward of Yokohama City. Dotted around this site are small scale industries of various natures. Yokohama is a major commercial hub in the Greater Tokyo Area. It has the second largest population (3.6 million) in Japan and is the most densely populated urban area after Tokyo. Yokohama City is predominantly residential with high density of road traffic, hosting five municipal incineration plants, three power plants and cement industries among other industrial and commercial activities. Industrial and commercial activities at the suburban residential area were substantially lower than at the urban residential area. Manufacturing of automobile parts, industrial machineries, producers of chemicals, pharmaceuticals, printing and packaging, electroplating, electronic products, and construction material and equipment are some of the industrial activities in the city. The distance between the two locations is about $12 \mathrm{~km}$. Considering the location and physical characteristic of the sampling sites, it was assumed that the above mentioned sites will help to predict the true facts of SPM associated PAHs pollution in urban residential and suburban residential area of Yokohama.

\section{Sample collection}

The SPM samples were collected with Shintaku Low Volume Air Sampler (Shintaku Co. Japan). It is a cyclone 


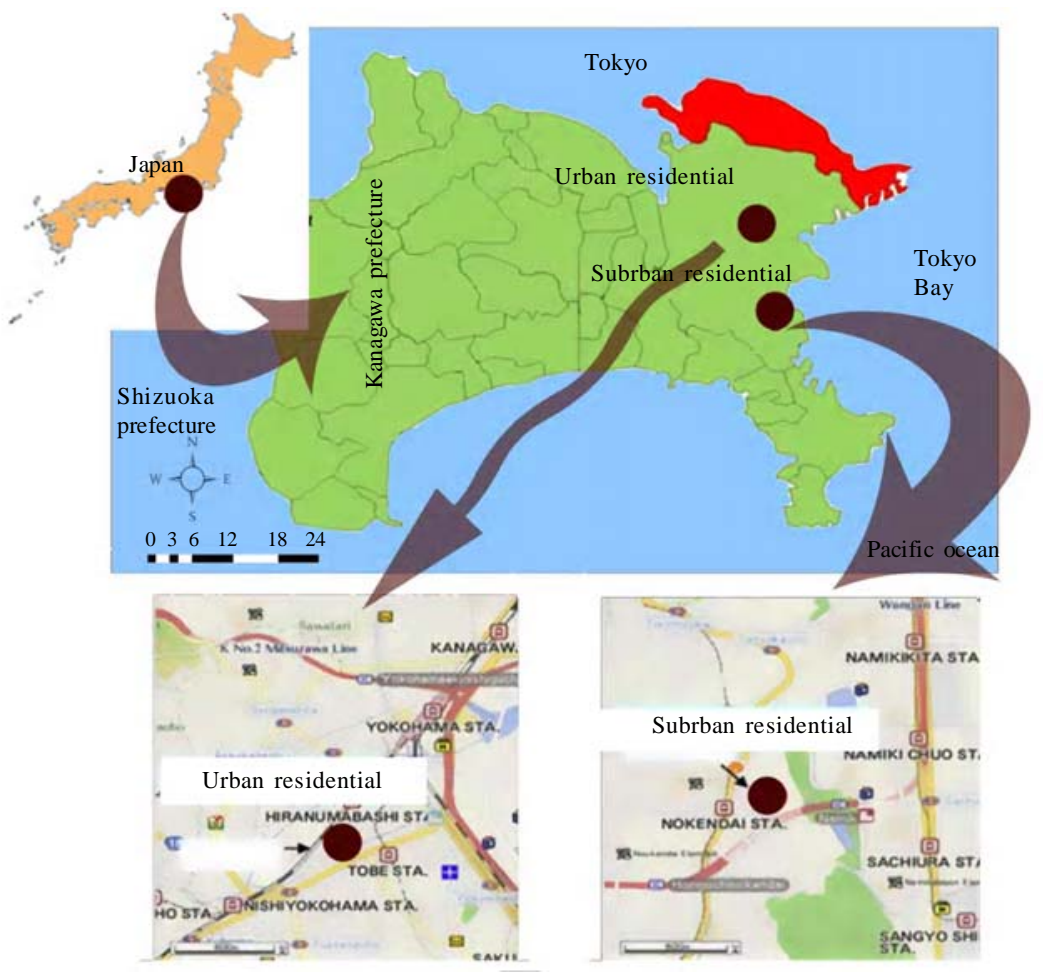

Fig. 1: MAP of the study sites: sample locations (upper map) and vicinity of sample locations (lower maps)

type air sampler and collects particles size at aerodynamic diameter $<10 \mu \mathrm{m}$ with $50 \%$ cut-off. At both locations, samplers were placed at about $3 \mathrm{~m}$ above the ground. The flow rate of the sampler was maintained at $20 \mathrm{~L} / \mathrm{min}$ during collection of samples in quartz filter paper (110 mm in diameter). Samples were collected monthly (30 days in each month) from April, 1999 to May, 2005. The samples for the year of 2003 were lost. The gravimetric mass was measured at controlled humidity (45\%) and temperature $\left(20^{\circ} \mathrm{C}\right)$.

\section{Target PAHs and reagents}

The target compounds of this study were ten types of PMs containing PAHs. The compounds monitored in this study, according to their elution orders were as follows: fluoranthene (Flt, m/z 202), pyrene (Pyr, m/z 202), benzo[a]anthracene (B[a]A, m/z 228), chrysene (Chry, m/z 228), benzo[b]fluoranthene (B[b]F, m/z 252), benzo[k]fluoranthene (B[k]F, m/z 252), benzo[e]pyrene (B[e]P, m/z 252), benzo[a]pyrene (B[a]P, m/z 252), indeno[1,2,3-cd]pyrene (Ind, $\mathrm{m} / \mathrm{z} 276$ ) and benzo[ghi]perylene (B[ghi]P, m/z 276).
PAHs standard mixture was purchased from AccuStandard, Inc. Quebec Ministry of Environ. (New Haven, USA). Internal standard solution component pyrene- $\mathrm{d}_{10}$ was purchased from Cambridge Isotope Laboratories, Inc. (Andover, MA). Surrogate solution component chrysene- $\mathrm{d}_{12}$ was purchased from Wako Pure Chemical (Osaka, Japan), perylene- $\mathrm{d}_{12}$ was from Kanto Chemical (Tokyo, Japan) and benzo[ghi]perylene- $\mathrm{d}_{12}$ was from $\mathrm{C} / \mathrm{D} / \mathrm{N}$ ISOTOPES (Quebec, Canada). Dichloromethane and hexane for extraction were residual pesticide analysis grade from Wako Pure Chemical (Osaka, Japan).

Analyses of ten SPM associated PAHs were performed on samples of suspended particulate matter which is recognized to be more appropriate indicator of higher molecular weight PAHs. Gas phase associated PAHs were not investigated, since the higher molecular weight PAHs targeted in this study, are present in air almost exclusively as particle bound compounds. These sorbed compounds are the most implicated in the human respiratory tract 
problems and associated with increased potential human health effects.

\section{Sample extraction and analysis}

The extraction method was adopted from Ohura et al. (2004) with minor modifications based on the instrument requirement and preliminary method experiment optimization. The SPM filters were cut into small pieces and placed into a $30 \mathrm{~mL}$ extraction glass tube wrapped with aluminum foil. It was extracted with $20 \mathrm{~mL}$ of dichloromethane containing four surrogate standards (phenanthrene $\mathrm{d}-{ }_{10}$, chrysene$d_{12}$, perylene- $d_{12}$ and benzo[ghi]perylene- $d_{12}$ ) in an ultrasonic bath (Sharp, UT-105S, Japan) for $20 \mathrm{~min}$, repeated for thrice. After that, extracts were combined and centrifuged at $3000 \mathrm{rpm}$ for $10 \mathrm{~min}$ to screen out the insoluble particles.

The clear supernatant was transferred to a round bottomed flask and was concentrated to about $3 \sim 5 \mathrm{~mL}$ in a Buchi syncore evaporator system at $40^{\circ} \mathrm{C}$ in water bath. The extract was transferred to a scaled test tube and further concentrated to near dryness by a gentle flow of nitrogen gas. The final extract was adjusted exactly to $1 \mathrm{~mL}$ by adding $0.9 \mathrm{~mL}$ of hexane and $100 \mu \mathrm{L}$ of $1 \mu \mathrm{g} / \mathrm{mL}$ internal standard (pyrene- $\mathrm{d}_{10}$ ) solution before being subjected to GC-MS analysis.

The samples were analyzed with a HewlettPackard GC/MS system consisting of a HewlettPackard Model 6890 gas chromatograph (GC) and a Hewlett-Packard model 5793 mass selective detector (MSD) with a capillary column (DB-5, $60 \mathrm{~m}, 0.25 \mathrm{~mm}$ i.d., $0.25 \mu \mathrm{m}$ film thickness) (Agilent Technologies, USA). The GC temperature was held at $65^{\circ} \mathrm{C}$ for 2 min and raised to $280^{\circ} \mathrm{C}$ at $6^{\circ} \mathrm{C} / \mathrm{min}$, held isothermally at $280^{\circ} \mathrm{C}$ for $20 \mathrm{~min}$ using helium as the carrier gas. A computer controlled automatic sampler was used in conjunction with the GC/MS system. All injections were in splitless mode with an injection volume of 1 $\mu \mathrm{L}$. The samples were first analyzed in the scan mode for qualitative analysis and finally by selective ion monitoring (SIM) mode for quantitative determination. Retention times were compared with those of external standards. Five calibration standard solutions containing the target PAHs, internal standard pyrene- $\mathrm{d}_{10}$, surrogate standards phenanthrene- $\mathrm{d}_{10}$, chrysene- $d_{12}$, perylene- $d_{12}$ and benzo[ghi]perylene- $d_{12}$, were carefully prepared and analyzed. Average response factors were calculated for each compound.
Quantification was performed from the GC profiles using the external standard method for 10 PAHs as follows: Flt (4-ring), Pyr (4-ring), Chry (4-ring), B[a]A (4-ring), B[b]F (5-ring), B[k]F (5-ring), B[e]P (5-ring), $\mathrm{B}[\mathrm{a}] \mathrm{P}$ (5-ring), Ind (6-ring) and $\mathrm{B}$ [ghi]P (6-ring).

\section{Quality assurance (QA) /Quality control (QC)}

$\mathrm{QA} / \mathrm{QC}$ was conducted to minimize and quantify sampling and measurement errors by carrying out field blanks and procedure blanks, surrogate recoveries, standard spikes recovery and certified reference material recovery. For every set of samples, procedural blanks were run to check the cross contamination. None of the target 10 PAHs was detected in procedural blank samples. All samples were spiked with surrogate standard prior to extraction. Recoveries of surrogate standards were $81 \pm 7 \%$ for phenanthrene- $\mathrm{d}_{10}, 87 \pm 5 \%$ for chrysene$\mathrm{d}_{12}, 96 \pm 9 \%$ for perylene- $\mathrm{d}_{12}$ and $98 \pm 10 \%$ for benzo[ghi]perylene- $d_{12}$. Recoveries of the following surrogate standards were used to correct the amounts of specific PAHs found in samples: phenanthrene- $d_{10}$ for Flt, chrysene- $d_{12}$ for Pyr, $\mathrm{B}[\mathrm{a}] \mathrm{A}$, and Chry, perylene- $\mathrm{d}_{12}$ for $\mathrm{B}[\mathrm{b}] \mathrm{F}, \mathrm{B}[\mathrm{k}] \mathrm{F}, \mathrm{B}[\mathrm{e}] \mathrm{P}$, and $\mathrm{B}[\mathrm{a}] \mathrm{P}$, and benzo[ghi]perylene- $\mathrm{d}_{12}$ for Ind, and $\mathrm{B}$ [ghi]P. Moreover, using certified reference material CRM-28, recovery analysis was done to check the retaining ability of target PAHs in archived samples. CRM 28 is a new environmental certified reference material, developed and certified by National Institute for Environmental Studies (NIES), Japan (Mori et al., 2008).

The average retaining abilities of PAHs were Flt (96\%), Pyr (98\%), B[a]A (96\%), B[b]F (96\%), B[k]F (96\%), B[a]Pyr (98\%), Ind (98\%) and B[ghi]P (96\%). Reproducibility of the PAH concentrations was studied as relative standard deviation (RSD) by 5 replicate analyses of the same aliquots. The RSD of the target PAHs ranged from $1 \%$ to $8 \%$, indicating good instrumental precision.

\section{RESULTS AND DISCUSSION}

Concentration of SPM

A total 41 of samples were respectively collected from each site in the urban residential and suburban residential area of Yokohama for the period of 1999 to 2005. The monthly SPM mass concentration varied from 19.7 to $50.3 \mu \mathrm{g} / \mathrm{m}^{3}$ with an overall mean concentration of $34.2 \mu \mathrm{g} / \mathrm{m}^{3}$ at the urban residential area. In contrast, 
monthly SPM mass ranged from 12.7 to $35.1 \mu \mathrm{g} / \mathrm{m}^{3}$ with an overall mean of $22.9 \mu \mathrm{g} / \mathrm{m}^{3}$ at the suburban residential area as shown in Table 1. One-way ANOVA was applied to the SPM data sets for these sites and the result revealed that the SPM concentration at downtown area was significantly higher $(\mathrm{p}<0.001)$ than suburban residential area. In addition, the yearly mean SPM at both locations exceeded the World Health Organization (WHO) air quality guideline of $20 \mu \mathrm{g} / \mathrm{m}^{3}$.

\section{Ambient levels of particulate PAHs}

Particulate matter collected from urban residential and suburban residential areas were analyzed for 10 types of PAHs. The mean concentration, maximum (max) and minimum ( $\mathrm{min}$ ) concentrations of individual PAHs arranged by sampling sites are given in Table 1 for the year 1999 to 2005 . The mean concentration of individual PAHs ranged from 0.09 to $0.45 \mathrm{ng} / \mathrm{m}^{3}$ and 0.04 to $0.20 \mathrm{ng} / \mathrm{m}^{3}$ for urban residential and suburban residential area, respectively. The results of present study were in agreement with individual PAH concentration reported by Tham et al. (2008) at Higashi Hiroshima, Japan. The most abundant PAHs (B[b]F, Ind, $\mathrm{B}[$ ghi $] \mathrm{P}$, and $\mathrm{B}[\mathrm{e}] \mathrm{P}$ ) showed average high concentrations accounting for $0.45,0.33,0.30$ and 0.27 $\mathrm{ng} / \mathrm{m}^{3}$ and $0.20,0.13,0.15$ and $0.11 \mathrm{ng} / \mathrm{m}^{3}$ at urban residential and suburban residential areas, respectively. The monthly total PAH concentrations over the whole sampling period at urban residential and suburban residential area ranged from 0.31 to $6.16 \mathrm{ng} / \mathrm{m}^{3}$ and 0.33 $\mathrm{ng} / \mathrm{m}^{3}$ to $2.87 \mathrm{ng} / \mathrm{m}^{3}$, respectively. Dominant 5-ring and 6-ring PAHs, known to be highly carcinogenic and mutagenic to human, accounted for $77.3 \%$ and $72.1 \%$ of total PAHs at urban residential and suburban residential areas, respectively while 4-ring PAHs showed the least contribution. The low concentrations of lower ring PAHs are consistent with their physiochemical properties. With high vapor pressure and high volatility, these compounds exist primarily in the gaseous phase (Tsapakis and Stephanou, 2005). In an earlier study in Japan, Ohura et al. (2004) focusing on gas-particle partitioning also suggested that higher ring PAHs were predominantly attached with particulate matter, while lower ring PAHs tended to exist in the gas phase only.

The urban residential area located near the downtown area of Yokohama recorded higher concentration levels than those found at the suburban residential area. The average recorded heavy duty (run by diesel) traffic density per $24 \mathrm{~h}$ was about 66,393 for the year 2005 at a highway (Kanagawa Route 1 Yokohane line) near to the urban residential area. Yokohama-Yokosuka highway, nearer to suburban residential site also turned out a heavy duty traffic density of 26,389 per $24 \mathrm{~h}$ in the same year (Ministry of Land, Infrastructure, and Transport, Japan 2005a, b). The mean concentration of SPM mass was $34.2 \mu \mathrm{g} / \mathrm{m}^{3}$ and $22.9 \mu \mathrm{g} / \mathrm{m}^{3}$ in urban residential and suburban residential area, respectively. The suburban residential site was about $12 \mathrm{~km}$ northwest of the urban residential area (downtown area) of Yokohama. The finding of the present study was consistent with the results of Hayakawa et al. (2002) regarding their study at Kanazawa in Japan. For both cities, roads are abundant in urban area than suburban area. PAHs emissions from roadways are known to be significant contributors to

Table 1: Average, minimum and maximum concentrations of SPM and individual SPM associated PAHs at urban residential and suburban residential area of Yokohama

\begin{tabular}{|c|c|c|c|c|c|c|}
\hline \multirow[t]{2}{*}{ Sampling site } & \multicolumn{3}{|c|}{ Urban residential } & \multicolumn{3}{|c|}{ Suburban residential } \\
\hline & Average $(\mathrm{N}=41)$ & Min & Max & Average $(\mathrm{N}=41)$ & Min & Max \\
\hline SPM $\left(\mathrm{ug} / \mathrm{m}^{3}\right)$ & 34.2 & 19.7 & 50.3 & 22.9 & 12.7 & 35.1 \\
\hline PAHs (ng/ m $\left.{ }^{3}\right)$ & & & & & & \\
\hline Fluoranthene & 0.112 & 0.017 & 0.840 & 0.099 & 0.038 & 0.420 \\
\hline Pyrene & 0.096 & 0.016 & 0.530 & 0.097 & 0.035 & 0.411 \\
\hline Benz[a]anthracene & 0.093 & 0.014 & 0.470 & 0.037 & 0.010 & 0.102 \\
\hline Chrysene & 0.169 & 0.019 & 0.830 & 0.052 & 0.017 & 0.108 \\
\hline Benzo[b]fluoranthene & 0.449 & 0.058 & 1.468 & 0.199 & 0.014 & 1.046 \\
\hline Benzo[k]fluoranthene & 0.153 & 0.020 & 0.504 & 0.059 & 0.019 & 0.130 \\
\hline Benzo[e]pyrene & 0.265 & 0.045 & 0.840 & 0.106 & 0.022 & 0.278 \\
\hline Benzo[a]pyrene & 0.094 & 0.018 & 0.390 & 0.092 & 0.024 & 0.501 \\
\hline Indeno[1,2,3-cd]pyrene & 0.332 & 0.036 & 1.255 & 0.134 & 0.037 & 0.578 \\
\hline Benzo[ghi]perylene & 0.306 & 0.042 & 1.075 & 0.146 & 0.040 & 0.603 \\
\hline Total PAHs & 2.067 & 0.331 & 6.164 & 1.021 & 0.333 & 2.874 \\
\hline
\end{tabular}


airborne PAHs in the central parts of large cities (Bostrom et al., 2002).

Fig. 2 and 3 show the higher concentration trends of individual PAHs and the $\mathrm{SPAHs}$ at urban residential and suburban residential areas of Yokohama. Strong monthly trends were observed for both individual PAHs concentration and the $\Sigma$ PAHs concentrations at the study sites. It is evident from Fig. 2 and 3 that higher concentration was found in colder months during November to February and lower concentrations in warmer months during May to September. During cold months average total concentration was $0.58 \mathrm{ng} / \mathrm{m}^{3}$ compared with $0.26 \mathrm{ng} / \mathrm{m}^{3}$ for warmer months in the suburban residential area. In the urban residential area, average total concentrations were $0.50 \mathrm{ng} / \mathrm{m}^{3}$ and $0.23 \mathrm{ng} / \mathrm{m}^{3}$ during cold and warm months, respectively. The average total PAHs concentrations were 3-6 times higher in January, February and December, compared to May, June and August in urban residential area (Fig. 2). It was 1-3 times higher in suburban residential area (Fig. 3). The present study showed higher levels of $\mathrm{B}[\mathrm{b}] \mathrm{F}, \mathrm{B}[\mathrm{k}] \mathrm{F}$ and $\mathrm{B}[\mathrm{ghi}] \mathrm{P}$ during winter and likely suggested an influence of local or regional emission sources.

It can be attributed to an increase in consumption of fossil fuel in winter. During the cold season, $\mathrm{PAH}$ emissions from automobile exhaust are higher because of low ambient temperature and increased cold start impacts (Ludykar et al., 1999). Sklorz et al. (2007) reported higher levels of $\mathrm{B}[\mathrm{a}] \mathrm{A}, \mathrm{B}[\mathrm{b}] \mathrm{F}, \mathrm{B}[\mathrm{k}] \mathrm{F}$ and Ind during winter. Additional emission of pollutants can be expected during winter from various sources such as domestic heating, power plant, etc. Besides these, in winter, the atmospheric condition is rather stagnant due to the frequent occurrence of low inversion layers. Under stagnant atmospheric condition, photodegradation and pollutant dispersion are least, resulting in the accumulation which in turn leads to a higher concentration of particulate PAHs (Sharma et al., 2007).

Benzo[a]pyrene has been suspected to be one of the most potent carcinogenic and genotoxic PAHs (WHO/IPCS, 1998). The mean concentration of B[a]P for urban residential and suburban residential areas were 0.091 and $0.085 \mathrm{ng} / \mathrm{m}^{3}$ ranging from 0.03 to 0.390 $\mathrm{ng} / \mathrm{m}^{3}$ and 0.024 to $0.501 \mathrm{ng} / \mathrm{m}^{3}$, respectively (Table $1)$. The concentration of $\mathrm{B}[\mathrm{a}] \mathrm{P}$ obtained in the current study was similar with other Japanese cities demonstrated by Ohura et al. (2004) in Fuji city (0.067 to $1.08 \mathrm{ng} / \mathrm{m}^{3}$ ) which is very near to Yokohama and Tham et al. (2008) in Higashi Hiroshima (0.52 \pm 0.42 $\left.\mathrm{ng} / \mathrm{m}^{3}\right)$. It can also be compared with some other urban areas in the world, for example, 0.23 to $0.73 \mathrm{ng} / \mathrm{m}^{3}$ in Birmingham, U.K (Harrison et al., 1996) and 0.39-2.33 $\mathrm{ng} / \mathrm{m}^{3}$ in Northern Greece (Papageorgopoulou et al., 1999).

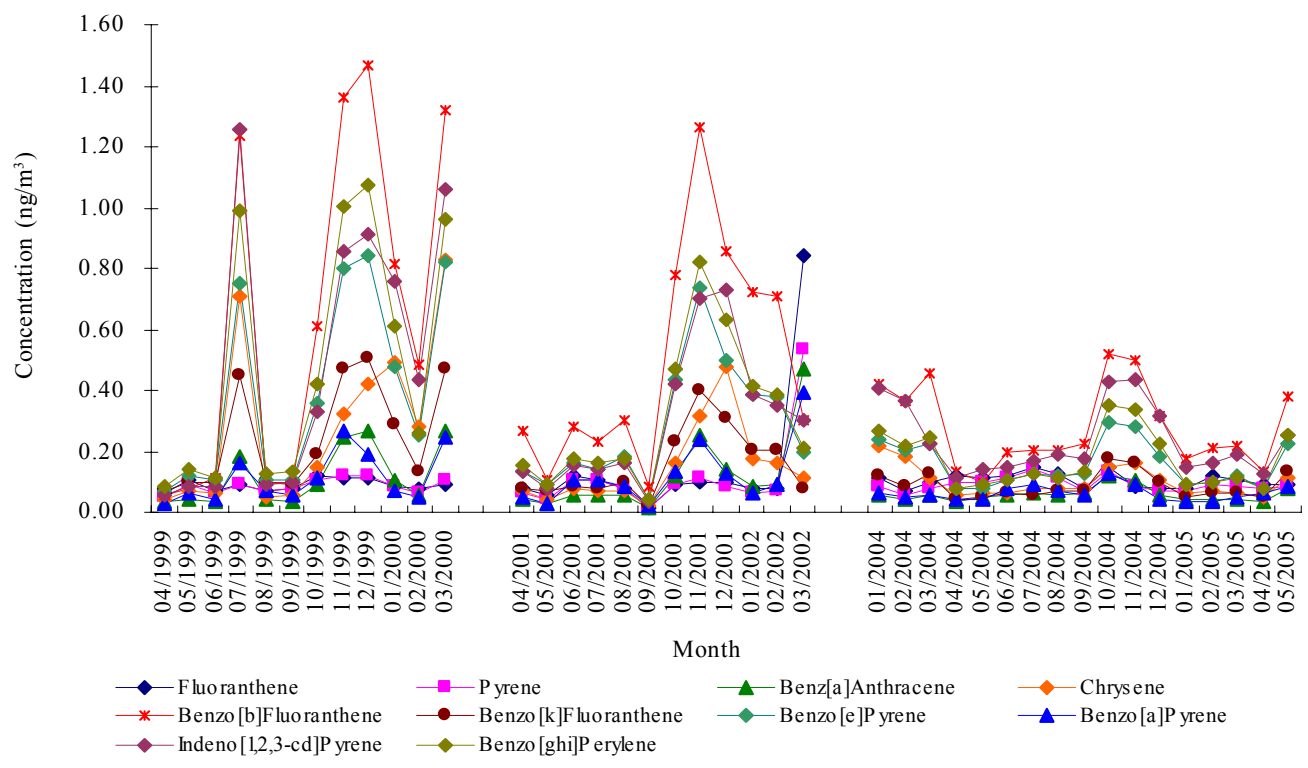

Fig. 2: Monthly trend of SPM associated PAHs at urban residential site 


\section{Source apportionment}

Ten SPM associated PAHs measured at urban residential and suburban residential of Yokohama were employed to know the source profiles of PAHs using principal component analysis (PCA). Many studies have applied PCA to study the potential source of particulate matter associated PAHs (Guo et al., 2003). PCA with varimax rotation was applied to the data matrix to explore and identify the main sources of atmospheric pollutants. PCA in the present study was carried out using the statistical analysis software package SPSS 11.5. Factors were extracted based on SPM associated PAHs concentration of the study sites. Table 2 provides the results of PCA for SPM associated PAHs of eigenvalues $>1.0$. PCA was carried out individually for each study site.

\section{Urban residential area}

Two factors were extracted for the urban residential area, accounting $95.8 \%$ of the total variance shown in

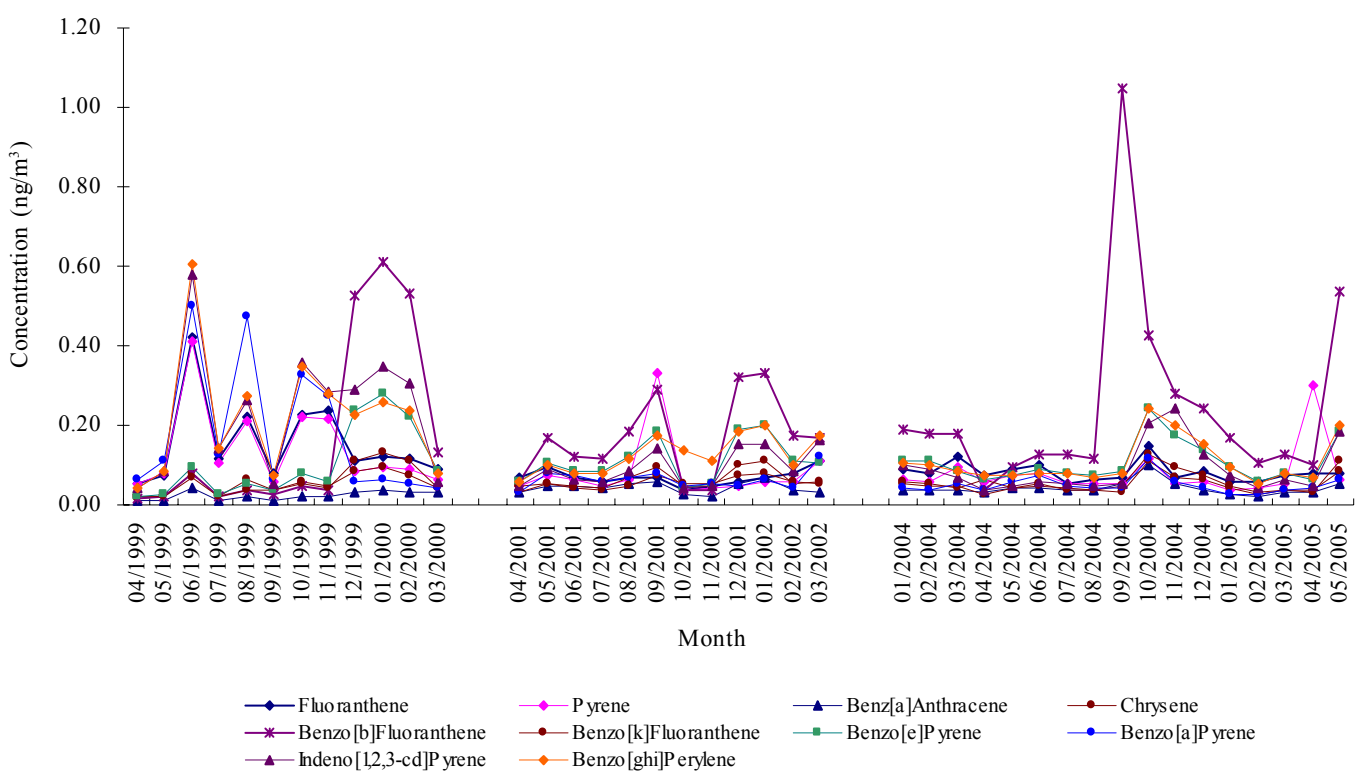

Fig. 3: Monthly trend of SPM associated PAHs at suburban residential area

Table 2: Factor loadings obtained from PCA on SPM associated PAHs at urban residential and suburban residential area of Yokohama, Japan

\begin{tabular}{lcccc}
\hline Sampling site & \multicolumn{2}{c}{ Urban residential } & \multicolumn{2}{c}{ Suburban residential } \\
\hline PAHs & Factor 1 & Factor 2 & Factor 1 & Factor 2 \\
Fluoranthene & -0.129 & 0.981 & 0.963 & -0.024 \\
Pyrene & -0.038 & 0.993 & 0.821 & -0.040 \\
Benz[a]anthracene & 0.588 & 0.795 & 0.045 & 0.755 \\
Chrysene & 0.913 & 0.049 & 0.388 & 0.863 \\
Benzo[b]fluoranthene & 0.977 & 0.109 & -0.123 & 0.769 \\
Benzo[k]fluoranthene & 0.987 & 0.073 & 0.150 & 0.954 \\
Benzo[e]pyrene & 0.985 & 0.126 & 0.075 & -0.966 \\
Benzo[a]pyrene & 0.568 & 0.786 & 0.933 & 0.377 \\
Indeno[1,2,3-cd]pyrene & 0.966 & 0.117 & 0.879 & 0.328 \\
Benzo[ghi]perylene & 0.987 & 0.115 & 0.922 & 4.03 \\
Eigen value & 6.33 & 3.26 & 4.29 & 40.34 \\
Variance (\%) & 63.27 & 32.61 & 42.91 & 83.25 \\
Cumulatives (\%) & 63.27 & 95.88 & 42.91 & Stationary \\
Origin & Stationary & Vehicular & Vehicular & \\
\hline
\end{tabular}


Table 2. Factor 1 accounted for $63.3 \%$ of the total variance and had high factor loading for light molecular weight PAHs such as Chry, and heavy molecular weight PAHs such as $\mathrm{B}[\mathrm{e}] \mathrm{P}, \mathrm{B}[\mathrm{K}] \mathrm{F}$ and $\mathrm{B}[\mathrm{b}] \mathrm{F}$, which are identified as markers of stationary (industry) sources (Kulkarni and Venkataraman, 2000; Fang et al., 2004; Yang et al., 1998). High factor loading of Ind and B[ghi]P were identified as gasoline emission (Khalili, et al., 1995; Marr et al., 1999; Fraser et al., 2000; Guo et al., 2003).Most of the PAHs with high factor loadings in factor 1 are the markers of stationary sources. Oil burning industries might have had an influence on combined extracted loading factor. Factor 2 is responsible for $32.6 \%$ of the total variance. This factor had high factor loadings for Flt and Pyre, which are indications of diesel emission (Yang et al., 1998; Kulkarni and Venkataraman, 2000; Ho et al., 2002; Fang et al., 2004). A moderate factor loading of $\mathrm{B}[\mathrm{a}] \mathrm{A}$ and $\mathrm{B}[\mathrm{a}] \mathrm{P}$ also found which perhaps related to gasoline emission. The presence of metallurgical industries, power plant, cements industries and incinerations in the vicinity of the urban residential area have been attributed to stationary sources. Hence, it could be suggested that stationary sources (Industries) form a potential fraction of particulate associated PAHs at urban residential area of Yokohama.

\section{Suburban residential area}

The nature of the sources in suburban residential area was different in some extent as shown in Table 2. Two factors were extracted by PCA and these accounted for $83.3 \%$ of the total variance in suburban residential area. Factor 1 accounted for $42.9 \%$ of the total variance and was associated with high factor loadings of Flt and Pyr. These compounds have been identified as coming from diesel emission sources (Yang et al., 1998; Marr et al., 1999; Kulkarni and Venkataraman, 2000; Ho et al., 2002; Fang et al., 2004).

Relatively higher factor loadings of B[a]P, Ind and $\mathrm{B}$ [ghi]P were reportedly identified as markers of gasoline emission (Khalili et al., 1995; Marr et al., 1999; Fraser et al., 2000; Guo et al., 2003). All these markers are indicators of emissions from vehicular (diesel and gasoline) transportation. Factor 2 was responsible for $40.3 \%$ of the total variance with high loadings of Chry, $\mathrm{B}[\mathrm{b}] \mathrm{F}, \mathrm{B}[\mathrm{k}] \mathrm{F}$ and $\mathrm{B}[\mathrm{e}] \mathrm{P}$, noted to be responsible for stationary emissions (Yang et al., 1998; Kulkarni and Venkataraman, 2000; Fang et al., 2004). It could be suggested that vehicular emissions (diesel and gasoline) and industrial emissions contributed almost equal sources of PAHs in the suburban residential area. Industrial activities were found substantially lower in suburban residential area than urban residential area in Yokohama.

\section{Impact of emission regulation}

SPM has been recognized as potent air pollutant in urban area of Japan and considered as criteria pollutant to be routinely monitored in ambient air. Japan is the most industrialized nation in Far East Asia. In 19501960 , the country experienced the worst air pollution in history. Industrial activities and increased number of automobiles were suspected to play key roles for the high emissions into ambient air. As a result, the Government of Japan took different initiatives through formulating and enacting different legislations and various measures to control SPM pollution in major cities across the country. Recently, the enforcement of emission regulation was commenced in October, 2002 as an effort to reduce the concentrations of SPM and nitrogen oxides (NOx) from the large cities across Japan.

Later on, another strict and new regulation was enacted and executed in October, 2003 on vehicle categories to attain the environmental quality standards for $\mathrm{NO}_{2}$ and SPM by FY 2010 based on three policies, namely, motor vehicles emission regulations on new vehicles, regulations on vehicles in use in specific areas and measures to promote the use of low pollution vehicles (Japan Environmental Council, 2003). The laws regulated gasoline/LPG and diesel motor vehicles. It was assumed that the aforesaid regulations would reduce emission significantly from both gasoline and diesel motor vehicles in large Japanese cities.

The regulation being enforced for diesel engine vehicles were particularly considered on the heavyduty vehicles namely buses and trucks. Near our sampling sites, the average traffic density was considerably high. The average traffic density per 12 hours for weekday and weekend were about 50487 and 31187, respectively for the year 2005 at a highway (Kanagawa Route 1 Yokohane line) of Yokohama. Heavy duty vehicle were recorded as half of the total traffic. This highway route is nearer to the urban residential site (Ministry of Land, Infrastructure and Transport, Japan 2005a).

Yokohama-Yokosuka highway is nearer to the suburban residential site and the traffic densities were reported as 19237 and 14766 for weekday and weekend, 
Int. J. Environ. Sci. Tech., 8 (2), 255-266, Spring 2011

Table 3: Concentration $\left(\mathrm{ng} / \mathrm{m}^{3}\right)$ reduction of SPM associated PAHs at urban residential and suburban residential area in Yokohama after the enforcement of emission regulations in 2002 and 2003

\begin{tabular}{|c|c|c|c|c|c|c|}
\hline \multirow{2}{*}{$\frac{\text { Sampling site }}{\text { Pre/Post regulation }}$} & \multicolumn{3}{|c|}{ Urban residential } & \multicolumn{3}{|c|}{ Suburban residential } \\
\hline & Before & After & Change & Before & After & Change \\
\hline PAHs & (1999-2002) & $(2004-05)$ & $(\%)$ & $(1999-2002)$ & $(2004-05)$ & $(\%)$ \\
\hline Fluoranthene & 0.117 & 0.104 & -11.5 & 0.112 & 0.081 & -27.7 \\
\hline Pyrene & 0.100 & 0.090 & -9.6 & 0.111 & 0.077 & -30.9 \\
\hline Benz[a]anthracene & 0.117 & 0.059 & -49.8 & 0.033 & 0.042 & +25.0 \\
\hline Chrysene & 0.218 & 0.100 & -54.2 & 0.054 & 0.049 & -8.9 \\
\hline Benzo[b]fluoranthene & 0.568 & 0.280 & -50.8 & 0.170 & 0.239 & +40.8 \\
\hline Benzo $[\mathrm{k}]$ fluoranthene & 0.199 & 0.087 & -56.5 & 0.060 & 0.058 & -4.5 \\
\hline Benzo[e]pyrene & 0.341 & 0.157 & -54.0 & 0.106 & 0.106 & 0.0 \\
\hline Benzo[a]pyrene & 0.116 & 0.063 & -45.7 & 0.122 & 0.050 & -58.7 \\
\hline Indeno[1,2,3-cd]pyrene & 0.400 & 0.235 & -41.3 & 0.164 & 0.090 & -44.9 \\
\hline Benzo[ghi]perylene & 0.402 & 0.171 & -57.4 & 0.173 & 0.107 & -38.0 \\
\hline Total PAHs & 2.579 & 1.35 & -47.8 & 1.106 & 0.900 & -18.6 \\
\hline
\end{tabular}

respectively per $12 \mathrm{~h}$ in the same year. Heavy-duty vehicles are mostly run by diesel engine while gasoline is mostly used in light-duty vehicles (Ministry of Land, Infrastructure and Transport, Japan, 2005b). For the present study, particulate matter associated PAHs were used to assess the impact of emission regulation for automobiles in large Japanese cities enacted during 2002 and 2003. A considerable resultant emission reduction was found at the urban residential site compared to the suburban residential area as shown in Table 3.

Based on the average total PAHs ( $\mathrm{PAHs}$ ) concentration, emission reduction was $48.7 \%$ and $18.6 \%$ in urban residential and suburban residential areas, respectively. Considering SPM mass and concentration of individual target PAHs, the magnitude of the emission reduction at the urban residential area was in the following order: $\mathrm{B}$ [ghi]P $(57.4 \%)>\mathrm{B}[\mathrm{k}] \mathrm{F}(56.4 \%)>\operatorname{Chry}(54.2 \%)>\mathrm{B}[\mathrm{e}] \mathrm{P}$ $(54.0 \%)>\mathrm{B}[\mathrm{b}] \mathrm{F}(50.8 \%)>\mathrm{B}[\mathrm{a}] \mathrm{A}(49.8 \%)>\mathrm{B}[\mathrm{a}] \mathrm{P}$ $(45.7 \%)>\operatorname{Ind}(41.3 \%)>\operatorname{Flt}(11.5 \%)>\operatorname{Pyr}(9.6 \%)$.

Thus, there were just marginal reductions in $\mathrm{Pyr}$ $(9.6 \%)$ and Flt (11.5\%) after the enforcement of the regulation. Since Pyr and Flt relates as source markers of diesel engine emission, it might suggest that heavy-duty vehicle run by diesel engine did not respond much to the enforcement of emission regulation. At the suburban residential area, the magnitude of emission reductions of target PAHs were shown in Table 3 as follows: $\mathrm{B}[\mathrm{a}] \mathrm{P}(58.7 \%)>$
Ind $(44.9 \%)>\mathrm{B}$ [ghi] $\mathrm{P}(38 \%)>\operatorname{Pyr}(30.9 \%)>$ Flt $(27.7 \%)>\operatorname{Chry}(8.9 \%)>\mathrm{B}[\mathrm{k}] \mathrm{F}(4.5 \%)$. The concentrations of $\mathrm{B}[\mathrm{a}] \mathrm{A}$ and $\mathrm{B}[\mathrm{b}] \mathrm{F}$ were nonetheless higher but $\mathrm{B}[\mathrm{e}] \mathrm{P}$ remained unchanged after the emission regulation enforcement at suburban residential area. $\mathrm{B}[\mathrm{a}] \mathrm{A}, \mathrm{BaP}$, Ind and BghiP are mainly the multi ringed, heavy molecular weight PAHs, which have been identified as source markers of gasoline engine emission (Marr et al., 1999; Fraser et al., 2000). As a result of emission regulations enforcement, the contribution of $\mathrm{B}[\mathrm{a}] \mathrm{P}$, Ind, and $\mathrm{B}$ [ghi]P were plausibly reduced by $45.7 \%, 41.3 \%$, $57.4 \%$ and $58.7 \%, 44.9 \%, 38.0 \%$ at the urban residential and suburban residential area, respectively. Thus, comparatively, reduction in gasoline engine emission was greater than diesel engine emission at both sites. Kulkarni and Ventakaraman, 2000; Fang et al. 2004; Yang et al. 1998 have been identified the lower molecular weight $\mathrm{PAH}$, Chry and higher molecular weight PAHs, B[b]F, $\mathrm{B}[\mathrm{k}] \mathrm{F}$, and $\mathrm{B}[\mathrm{e}] \mathrm{P}$ as markers of stationary sources. These compounds were reduced at $54.2 \%, 50.8 \%$, $56.5 \%$ and $54.0 \%$ in the urban residential area.

In the case of the suburban residential area, these compounds showed minor reduction 0-8.9\% except $\mathrm{B}[\mathrm{b}] \mathrm{F}$ which was increased $40.8 \%$ after the enforcement of emission regulation. $\mathrm{B}[\mathrm{b}] \mathrm{F}$ is one of the major source markers of industrial emission. At the suburban residential area, diesel emission markers showed reduction three times greater than the urban 
residential area. Considering overall features, the lower impact of emission regulation at suburban residential area suggested that SPM pollution might be other than the automobile emission.

Industrial activities surrounding the study area such as incineration, petrochemical activities, power plant and printing and packaging industries at this location might have released these compounds of SPM pollution. SPM pollution was reduced by $27 \%$ and 13 $\%$ at urban residential and suburban residential area, respectively, after the enforcement of emission regulation.

\section{CONCLUSION}

Measurement of suspended particulate matter and determination of ten SPM associated PAH concentrations were performed in urban residential and suburban residential area of Yokohama, for the period of 1999-2005. The mean concentrations of SPM aerosol were 34.2 and $22.9 \mu \mathrm{g} / \mathrm{m}^{3}$ at urban residential and suburban residential area, respectively. The predominant PAHs determined were BbF, Ind, BghiP, and $\mathrm{BeP}$ for both of the study sites. Dominant 5-ring and 6-ring PAHs, known to be highly carcinogenic and mutagenic to human, accounted for $77.3 \%$ and $72.1 \%$ of total PAHs at urban residential and suburban residential areas, respectively while 4-ring PAHs showed the least contribution.We found strong seasonal variation of PAHs, with higher levels in colder months during November to February and lower in warmer months during May to September. SPM associated PAHs were more elevated in urban residential area than suburban residential area of Yokohama. The results obtained from PCA revealed that vehicle emission and stationary (Industries) were probably the major pollutant sources for SPM associated PAHs in both of the study sites. As a result of the enforcement of automobile emission regulations, the following were the magnitude and order of reductions for SPM associated PAHs at urban residential area: $\mathrm{B}[$ ghi] $\mathrm{P}(57.4 \%)>\mathrm{B}[\mathrm{k}] \mathrm{F}(56.4 \%)>\mathrm{Chr}$ $(54.2 \%)>\mathrm{B}[\mathrm{e}] \mathrm{P}(54.0 \%)>\mathrm{B}[\mathrm{b}] \mathrm{F}(50.8 \%)>\mathrm{B}[\mathrm{a}] \mathrm{A}(49.8$ $\%)>\mathrm{B}[\mathrm{a}] \mathrm{P}(45.7 \%)>\operatorname{Ind}(41.3 \%)>\operatorname{Flt}(11.5 \%)>\mathrm{Pyr}$ $(9.6 \%)$

At suburban residential area, the resultant reduction of SPM associated PAHs were also represented as follows: $\mathrm{B}[\mathrm{a}] \mathrm{P}(58.7 \%)>\operatorname{Ind}(44.9 \%)>\mathrm{B}[\mathrm{ghi}] \mathrm{P}(38 \%)>$ Pyr $(30.9 \%)>$ Flt $(27.7 \%)>\operatorname{Chry}(8.9 \%)>B[k] F(4.5$ $\%)$. Based on the average total PAHs ( $\mathrm{PAHs}$ ) concentration, emission reduction was $48.7 \%$ and 18.6 $\%$ in urban residential and suburban residential areas, respectively.

Additionally, the impact of emission regulation was studied in consideration of SPM, which was found to be reduced by $27 \%$ and $13 \%$ at urban residential and suburban residential area, respectively. Comparatively, a lower impact of the emission regulations was observed at suburban residential area. So the emission regulations which were imposed for the reduction of diesel engine emission was to some extend effective in the study area. It can therefore, be proposed that some more effective new regulations should be taken to reduce atmospheric pollution in Yokohama to protect human health because of the exposure of carcinogenic PAHs through inhalation.

\section{ACKNOWLEDGEMENTS}

This study was supported by the Environmental Problem Research Aid of the Nippon Life Insurance Foundation. The authors would like to express their gratitude to Dr. Yasuyuki Zushi, Dr. Satoshi Managaki and Mr. Jonathan Hogarh for their assistance during manuscript preparation. The authors also express their gratitude to Dr. Susumu Konuma for his assistance during the experiment.

\section{REFERENCES}

Arulazhagan, P.; Vasudevan, N.; Yeom, I. T., (2010). Biodegradation of polycyclic aromatic hydrocarbons by a halotolearnt bacterial consortium isolated from marine environment. Int. J. Environ. Sci. Tech., 7 (4), 839-852 (14 pages).

Bandyopadhyay, G.; Chattopadhyay, S., (2007). Single hidden layer artificial neural network models versus multiple linear regression model in forecasting the time series of total ozone. Int. J. Environ. Sci. Tech., 4 (1), 141-150 (10 pages).

Bostrom, C. E.; Gerde, P.; Hanberg, A.; Jernstrom, B.; Johansson, C.; Kyrklund, T.; Rannug, A.; Tornqvist, M.; Victorin, K.; Westernholm, R., (2002). Cancer risk assessment, indicators, and guidelines for polycyclic aromatic hydrocarbons in the ambient air. Environ. Health Perspective, 110 (Suppl. 3), 451-488 (38 pages).

Breivik, K.; Vestreng, V.; Rozovskaya, O.; Pacyna, J. M., (2006). Atmospheric emission of some PoPs in Europe: A discussion of exiting inventories and data need. Environ. Sci. Policy, 9 (7-8), 663-674 (12 pages).

Chakra, O. R. A.; Joyeux, M.; Nerriere, E.; Strub, M. P.; ZmirouNavier, D., (2007). Genotoxicity of organic extracts from urban air particulate matter: An assessment within a personal exposure study. Chemosphere, 66 (7), 1375-1381 (7 pages).

Dockery, D. W.; Pope, C. A.; Xu, X.; Spengler, J. D.; Ware. J. H.; Fay, M. E.; Ferris, B. G.; Speizer, F. E., (1993). An association between air pollution and mortality in six U.S 
cities. The New England J. Med., 329 (24), 1753-1759 (8 pages).

Fagbote, E. O.; Olanipekun, E. O., (2010). Levels of polycyclic aromatic hydrocarbons and polychlorinated biphenyls in sediment of bitumen deposit impacted area. Int. J. Environ. Sci. Tech., 7 (3), 561-570 (10 pages).

Fang, G. C.; Wu, Y. S.; Chen, M. H.; Ho, T. T.; Huang, S. H.; Rau, J. J. Y., (2004). Polycyclic aromatic hydrocarbons study in Taichung, Taiwan, during 2002-2003. Atmos. Environ., 38 (21), 3385-3391 (8 pages).

Feng, D.; Huang W. L.; Yang C.; Dang, Z., (2009). Chemical speciation of fine particle bound trace metals. Int. J. Environ. Sci. Tech., 6 (3), 337-346 (10 pages).

Fraser, M. P.; Kleeman, M. J.; Schauer, J. J.; Gass, G. R., (2000). Modeling the atmospheric concentrations of individual gasphase and particle-phase organic compounds. Environ. Sci. Tech., 34 (7), 1302-1312 (11 pages).

Gilli, G.; Pignata, C.; Schiliro, T.; Bono, R.; Rosa, A. L.; Traversi, D., (2007). The mutagenic hazards of environmental $\mathrm{PM}_{2.5}$ in Turin. Environ. Res., 103 (2), 168175 (8 pages).

Goyal, P.; Sharma, P.; Srivastava, S.; Srivastava, M. M., (2008). Saraca indica leaf powder for decontamination of $\mathrm{Pb}$ : Removal, recovery, adsorbent characterization and equilibrium modeling. Int. J. Environ. Sci. Tech., 5 (1), $27-$ 34 (8 pages).

Guo, H.; Lee, S. C.; Ho, K. F.; Wang, X. M.; Zou, S. C., (2003). Particle-associated polycyclic aromatic hydrocarbons in urban air of Hong Kong. Atmos. Environ., 37 (38), 53075317 (11 pages).

Harrison, R. M.; Smith, D. J. T.; Luhana, L., (1996). Source apportionment of atmospheric polycyclic aromatic hydrocarbons collected from an urban location in Birmingham, U. K. Environ. Sci. Tech., 30 (3), 825-832 (8 pages).

Harrison, R. M.; Yin, J., (2000). Particulate matter in the atmosphere: Which particle properties are important for its effects on health? Sci. Total Environ., 249 (1-3), 85101 (17 pages).

Hayakawa, K.; Tang, N.; Akutsu, K.; Murahashi, T.; Kakimoto, H.; Rizu, R.; Toriba, A., (2002). Comparision of polycyclic aromatic hydrocarbons and nitropolycyclic aromatic hydrocarbons in airborne particulates collected in downtown and suburban Kanazawa, Japan. Atmos. Environ., 36 (35), 5535-5541 (7 pages).

He, Y.; Duan, C.; Wang, H.; Zhao, Y.; Tao, D., (2011). Separation of metal laden waste using pulsating air dry material separator. Int. J. Environ. Sci. Tech., 8 (1), 73-82 (10 pages).

Ho, K. F.; Lee, S. C.; Chiu, G. M. Y., (2002). Characterization of selected volatile organic compounds, polycyclic aromatic hydrocarbons and carbonyl compounds at a roadside monitoring station. Atmos. Environ., 36 (1), 57-65 (9 pages).

Jacobson, M. Z., (2002). Control of fossil-fuel particulate black carbon and organic matter, possibly the most effective method of slowing global warming. J. Geophys. Res., 107 (D19), 4410-4432 (33 pages).

Japan Environmental Council, (2003). Future policy for motor vehicle exhaust emission reduction, $6^{\text {th }}$ report (English report), June, 30 .
Khalili, N. R.; Scheff, P. A.; Holsen, T. W., (1995). PAH source fingerprints for coke ovens, diesel and gasoline engines, highway tunnels, and wood combustion emissions. Atmos. Environ., 29 (4), 533-542 (10 pages).

Khanfekr, A.; Arzani, K.; Nemati, A.; Hosseini, M., (2009). Production of perovskite catalysts on ceramic monoliths with nanoparticles for dual fuel system automobilies. Int. J. Environ. Sci. Tech., 6 (1), 105-112 (12 pages).

Kulkarni, P.; Venkataraman, C., (2000). Atmospheric polycyclic aromatic hydrocarbons in Mumbai, India. Atmos. Environ., 34 (17), 2785-2790 (6 pages).

Kumar, V.; Kothiyal, N. C., (2011). Distribution behavior of polycyclic aromatic hydrocarbons in roadside soil at traffic intercepts within developing cities. Int. J. Environ. Sci. Tech., 8 (1), 63-72 (12 pages).

Ludykar, D.; Westerholm, R.; Almen, J., (1999). Cold start emissions at $+22,-7$ and -20 degrees $\mathrm{C}$ ambient temperatures from a three-way catalyst (TWC) car: Regulated and unregulatedexhaust components. Sci. Total Environ., 235 (13), 65-69 (5 pages).

Manoli, E.; Kouras, A.; Samara, C., (2004). Profile analysis of ambient and source emitted particle-bound polycyclic aromatic hydrocarbons from three sites in northern Greece. Chemosphere, 56 (9), 867-878 (12 pages).

Mantis, J.; Chaloulakou, A.; Samara, C., (2005). PM10-bound polycyclic aromatic hydrocarbons (PAHs) in the greater area of Athens, Greece. Chemosphere, 59 (5), 593-604 (12 pages).

Marr, L. C.; Kirchstetter, T. W.; Harley, R. A.; Miguel, A, H.; Hering, S, V.; Hammond, S. K., (1999). Characterization of polycyclic aromatic hydrocarbons in motor vehicle fuels and exhausts emissions. Environ. Sci. Tech., 33 (18), 3091-3099 (9 pages).

McCrillis, R. C.; Watts, R. R.; Warren, S. H., (1992). Effects of operating variables on PAH emissions and mutagenicity of emissions from wood stoves. J. Air Waste Manage. Assoc., 42 (5), 691-694 (4 pages).

Ministry of land, infrastructure and transport, Japan, (2005a). Report of road traffic census in Yokohama.

Ministry of land, infrastructure and transport, Japan, (2005b). Report of road traffic census in Yokohama. (http:// www.ktr.mlit.go.jp/honkyoku/road/census/h18/pdfs/ kanagawa_pdf/kanagawa_r16.pdf)

Mori, I.; Sun, Z.; Ukachi, M.; Nagano, K.; Mcleod, C. W.; Cox, A. G.; Nishikaga, M., (2008). Development and certification of the new NIES CRM 28: Urban aerosols for the determination of multielements. Anal. Bioanal. Chem., 391 (6), 1997-2003 (7 pages).

Murakami, Y.; Ono, M., (2006). Myocardial infarction deaths after high level exposure to particulate matter. J. Epidem. Commun. Health, 60 (3), 262-266 (5 Pages).

Ohura, T.; Amagi, T.; Fusaya, M.; Matsushita, H., (2004). Spatial distribution and profiles of atmospheric polycyclic aromatic hydrocarbons in two industrial cities in Japan. Environ. Sci. Tech., 38 (1), 49-55 (7 pages).

Omori, T.; Fujimoto, G.; Yoshimura, I.; Nitta, H.; Ono, M., (2003). Effects of particulate matter on daily mortality in 13 Japanese cities. J. Epidemiol., 13 (6), 314-322 (9 Pages). Pagageorgopoulou, A.; Manoli, E.; Touloumi, E.; Samara, C., (1999). Polycyclic aromatic hydrocarbons in the ambient air of Greek towns in relation to other atmospheric pollutants. Chemosphere, 39 (13), 2183-2199 (17 Pages). 
Pope, C. A.; Dockery, D. W.; Schwartz, J., (1995a). Review of epidemiological evidence of health effects of particulate air pollution. Inhal. Toxicol., 7 (1), 1-18 (18 Pages).

Pope $3^{\text {rd }}$ C. A.; Thun, M. J.; Namboodiri, M. M.; Dockery, D. W.; Evans, J. S.; Speizer, F. E.; Heath Jr, C. W., (1995b). Particulate air pollution as a predictor of mortality in a prospective study of US adults. Am. J. Resp. Crit. Care Med., 151 (3), 669-674 (6 pages).

Pope $3^{\text {rd }}$, C. A.; Dockery, D. W., (2006). Health effects of fine particulate air pollution: Line that connect. J. Air Waste Manage. Assoc., 56 (3), 709-742 (34 pages).

Pozzi, R.; Berardis, B. D.; paoletti, L.; Guastadisegni, C., (2005). Winter urban air particles from Rome (Italy): Effects on the monocytic-macrophagic RAW 264.7 cell line. Environ. Res., 99 (3), 344-354 (11 pages).

Ravindra, K.; Mittal, A. K.; Van Grieken, R., (2001). Health risk assessment of urban suspended particulate matter with special reference to polycyclic aromatic hydrocarbons: A review. Rev. Environ. Health, 16 (3), 169-189 (21 pages).

Sharma, H.; Jain, V. K.; Khan, Z. H., (2007). Characterization and source identification of polycyclic aromatic hydrocarbons (PAHs) in the urban environment of Delhi. Chemosphere, 66 (2), 302-310 (9 pages).

Skarek, M.; Janosek, J.; Cupr, P.; Kohoutek, J.; NovotnaRychetska, A.; Holoubek, I., (2007). Evaluation of genotoxic and non-genotoxic effects of organic air pollution using in vitrobioassays. Environ. Int., 33 (7), 859-866 (8 pages).

Sklorz, M.; Schnelle-Kreis, J.; Liu, Y.; Orasche, J.; Zimmermann, R., (2007). Daytime resolved analysis of polycyclic aromatic hydrocarbons in urban aerosol samplesimpact of sources and meteorological conditions. Chemosphere, 67 (5), 934-944 (10 pages).

Tham, Y. W. F.; Takeda, K.; Sakugawa, H., (2008). Polycyclic aromatic hydrocarbons (PAHs) associated with atmospheric particles in Higashi Hiroshima, Japan: Influence of meteorological conditions and seasonal variations. Atmos. Res., 88 (3-4), 224-233 (12 pages).
Tsapakis, M.; Stephanou, E. G., (2005). Polycyclic aromatic hydrocarbons in the atmosphere of the Eastern Mediterranean. Environ. Sci. Tech., 39 (17), 6584-6590 (7 pages)

Venkataraman, C.; Lyons, M. J.; Friedlander, S. K.; (1994). Size distribution of aromatic hydrocarbons and elemental carbon. 1. sampling, measurement methods and source characterization. Environ. Sci. Tech., 28 (4), 555-562 (8 pages).

Wilson, A. M.; Salloway, J. C.; Wake, C. P.; Kelly, T., (2004). Air pollution and demand for hospital services: A review. Environ. Int., 30 (8), 1109-1018 (12 pages).

WHO, (1998). Selected Non-heterocyclic Polycyclic Hydrocarbons. World Health Organization, in: WHO International Programme on Chemical Safety (IPCS): Environ. Health Criteria 202., WHO, Geneva.

WHOE, (2005). Particulate matter air pollution: How it harms health, 1-4. World Health Organization Europe, Available at: http://www.chaseireland.org/Documents/WHOParticulateMattern.pdf

Wu, J.; He, Ch., (2010). Experimental and modeling investigation of sewage solids sedimentation based on particle size distribution and fractal dimension. Int. J. Environ. Sci. Tech., 7 (1), 37-46. (10 pages).

Yamazaki, S.; Nitta, H.; Ono, M.; Green, J.; Fukuhara, S., (2007). Intracerebral haemorrhage associated with hourly concentration of ambient particulate matter: Casecrossover analysis. Occup. Environ. Med., 64 (1), 17-24 (8 pages).

Yang, H. H.; Lee, W. J.; Chen, S. J.; Lai, S, O., (1998). PAH emission from various sources industrial stacks. J. Hazard. Mater., 60 (2), 159-174 (16 pages).

Yorifuji, T.; Yamamoto, E.; Tsuda, T.; Kawakami, N., (2005). Health impact assessment of particulate matter in Tokyo, Japan. Archives of Environ. Occup. Health., 60 (4), 179185 (7 pages).

\section{AUTHOR (S) BIOSKETCHES}

Salam, M. A., M.Sc., Ph.D., Research student; Graduate School of Environment and Information Sciences, Yokohama National University, Yokohama, Japan. E-mail: s_salam1978@yahoo.com

Shirasuna, Y., M.Sc., Scientist of Air Pollution Division, Yokohama City Research Institute for Environmental Science, Yokohama, Japan. E-mail: yu00-shirasuna@city.yokohama.jp

Hirano, K., M.Sc., Chief Scientist, Air Pollution Division, Yokohama City Research Institute for Environmental Science, Yokohama, Japan. E-mail: ko00-hirano@city.yokohama.jp

Masunaga, S., M.Sc., Ph.D., Professor; Graduate School of Environment and Information Sciences, Yokohama National University, Yokohama, Japan. E-mail: masunaga@ynu.ac.jp 